\title{
Cisza w nabożeństwie prawosławnym
}

\author{
o. Marek Lawreszuk \\ Katedra Teologii Prawosławnej \\ Uniwersytet w Białymstoku \\ Polska \\ xmlawreszuk@gmail.com
}

rev. Marek Ławreszuk, Silence in Orthodox church service, Elpis, 19 2017: 79-84.

\begin{abstract}
When analyzing the contemporary Orthodox liturgical tradition, we will hardly find in it silent. This article is to show that this element is not unfamiliar in the Orthodox liturgics and that it has its place and its purpose.

Streszczenie: Analizując współczesną prawosławną tradycję liturgiczną z trudem odnajdziemy w niej ciszę. Niniejszy artykuł ma za zadanie ukazać, że element ten nie jest w prawosławnej liturgice obcy oraz że posiada w niej swoje miejsce i celowość.
\end{abstract}

Keywords: Liturgy, liturgics, Orthodoxy, church service, silence, silent prayers

Słowa kluczowe: liturgia, liturgika, Prawosławie, nabożeństwo, cisza, ciche modlitwy

Prawosławna tradycja liturgiczna charakteryzowana jest przez pryzmat rozwiniętej sfery muzycznej. Śpiew liturgiczny, muzyka cerkiewna - te określenia jednoznacznie wskazują na związek nabożeństwa prawosławnego ze śpiewem. Bogata hymnografia, obecność historycznych tradycji śpiewu, a także sama struktura nabożeństw, sprawia, że związek ten wydaje się nierozerwalny i naturalny.

Obecnie kwestia ciszy w nabożeństwie omawiana jest głównie w aspekcie modlitw czytanych przez kapłana. Zagadnienie to w historycznym ujęciu opracował m.in. archimandryta Robert Taft, skupiając się na modlitwach kanonu eucharystycznego ${ }^{1}$. Kwestia cichych modlitw kapłańskich była również analizowana w pracy ks. Henryka Paprockiego $^{2}$. Badania w tym kierunku nie są jednak związane z naszym tematem, albowiem w chwilach cichych modlitw kapłana świątynia nie jest pogrążona w ciszy. Ten moment został w nabożeństwie zagospodarowany rozwiniętym śpiewem chóru.

Kwestia ciszy w nabożeństwie nie dotyka tylko modlitw kapłańskich, które stały się ciche dopiero około VIII-XI wieku³. Cisza w nabożeństwie pojawia się znacznie

\footnotetext{
Zob. Евхаристическая Анафора возносилась тайно или гласно? [w:] Р. Ф. Тафт, Статьи. II. Литургика, Голованов, Омск 2011, s. 253-302. Было ли традиционно для ранней Церкви чтение вслух литургических молитв? [w:] Р. Ф. Тафт, Статьи. ІІ. Литургика, Голованов, Омск 2011, s. 303-310.

Zob. również A. П. Голубцов, О причинах и времени замены гласного чтения литургийных молитв тайными, „Богословский вестник”, 1905, nr 9, s. 69-70.

2 H. Paprocki, Misterium Eucharystii. Interpretacja genetyczna Liturgii bizantyjskiej, Wydawnictwo

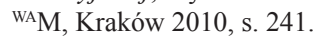

3 В. Алымов, Лекции по Исторической Литургике, Holy Trinity Orthodox School, maszynopis, http://www.holytrinitymission.org/books/ russian/historical_liturgics_v_alimov.zip, 16.06.2012, s. 117. Więcej na ten temat zob. również: M. Ławreszuk, Modlitwa wspólnoty: historyczny rozwój prawosławnej tradycji liturgicznej, Wydawnictwo Uniwersytetu
}

wcześniej. Jej obecność nie prowokowała również do rozprzestrzeniania się śpiewów w momentach ciszy.

\section{Najstarsza praktyka monastyczna - praktyka egipska}

W rozwoju prawosławnej tradycji liturgicznej istotnym punktem, wyznaczającym nowy kierunek rozwoju, była praktyka pustelnicza. Ludzie, którzy wybierali życie pustelnicze, rozwinęli nową praktykę modlitwy indywidualnej. Działanie to nie było prowokowane chęcią reformy, lecz wynikała z praktycznych potrzeb. Pierwotna forma monastycyzmu, pustelnictwo, nie pozwalała na uczestnictwo w dotychczasowym cyklu nabożeństw i oznaczała oddalenie się nie tylko od miast, ale i od istniejących tam wspólnot. W praktyce egipskiej rozwijała się praktyka modlitwy indywidualnej. Każdy asceta opierał się przy tym na własnej praktyce. Powstanie monastycyzmu wspólnotowego (cenobitycznego) doprowadziło do znacznych zmian w sferze modlitewnej. Modlitwa nie musiała być już dłużej indywidualna. W najwcześniejszym okresie zauważamy dwa nurty w monastycznej tradycji liturgicznej: wskazanie na indywidualny rytm modlitewny oraz wskazanie na konieczność wspólnej modlitwy.

Wspólna modlitwa mnichów w tradycji egipskiej oparta była na tzw. „Regule anielskiej”4. Na cykl dobowy składały się dwa nabożeństwa - wieczorne i poranne. Pierwsze z nich, określane jako czuwanie, stanowiło modlitwę 12 psalmów. Nabożeństwo rozpoczynało się po zachodzie słońca. W jego trakcie czytano 12 psalmów, po których czytano „Alleluja”. Po każdym psalmie mnisi stali

\footnotetext{
w Białymstoku, Białystok 2014, s. 343-345.

4 M. Ławreszuk, Modlitwa wspólnoty..., dz. cyt., s. 87.
} 
w ciszy, pogrążeni w modlitwie i dopiero na znak przełożonego czynili pokłon, po którym przełożony czytał modlitwę.

Późniejszy rozwój liturgicznej praktyki monastycznej zachował i rozpowszechnił nabożeństwo 12 psalmów. W tradycji kapadockiej było ono sprawowane dwukrotnie w ciągu dnia: rano i wieczorem. Struktura 12 psalmów, przejęta z „Anielskiej reguły” stała się następnie fundamentem późniejszych cyklów 6 psalmów porannych jutrzni oraz 6 wieczornych, które współcześnie stanowią szkielet nabożeństwa powieczerza ${ }^{6}$. Nabożeństwo 12 psalmów stało się również podstawą wielu najstarszych reguł skitów?

Monastyczne nabożeństwo wskazuje więc na chwile ciszy, które następowały po odczytaniu psalmu. Cisza ta nie była przerwą w nabożeństwie, lecz wyznaczała czas na indywidualną modlitwę i kontemplację.

Nabożeństwo 12 psalmów wskazuje na jeszcze jeden element, który będzie przez nas wkrótce omówiony. Podstawowa struktura tego nabożeństwa może być przez nas uporządkowana $\mathrm{w}$ następujący schemat: psalm, alleluja, cisza, wezwanie i modlitwa przełożonego ${ }^{8}$. Już św. Pachomiusz Wielki (292-346) wspominał o sześciu modlitwach wieczornych korespondujących z treścią czytanych wcześniej psalmów. Podobne świadectwo pozostawił także św. Warsonofiusz (+540), który pisał, iż „po każdym psalmie, zamiast doksologii, wygłaszano alleluja i czytano modlitwę"".

Interesujący ślad tej starej praktyki może zostać dostrzeżony w spisanych już w II tysiącleciu „Typikonach” tradycji neopalestyńskiej. W komentarzach dotyczących jutrzni możemy odnaleźć informację o śpiewie sześciu psalmów oraz ,zachowaniu w tym czasie ciszy” przez pozostałych ${ }^{10}$. Przy braku podobnych wskazań dotyczących innych fragmentów nabożeństw, pozwala to nam przypuszczać, że nie mamy w tym miejscu do czynienia z komentarzem dotyczącym ładu i porządku w trakcie nabożeństwa, lecz wskazanie stanowiące echo praktyki nabożeństwa 12 psalmów, ma skłonić do żarliwej indywidualnej modlitwy, modlitwy w ciszy. Również współczesne komentarze „Horologionu" dotyczące czytania sześciu psalmów jutrzni mogą być przez nas analizowane, nie w duchu organizacyjnym, lecz w kategorii wskazania na historyczną praktykę modlitwy w ciszy ${ }^{11}$.

\footnotetext{
И. Д. Мансветов, Церковный устав (Типик), его образование и судьба в греческой и русской

ие ркви, Москва 1885, s. 37.

6 И. Д. Мансветов, Церковный устав..., dz. суt., s. 26.

M. Ławreszuk, Modlitwa wspólnoty..., dz. cyt., s. 439.

M. Lawreszuk, Modlitwa wspólnoty..., dz. cyt., s. 87-90.

И. Д. Мансветов, Церковный устав..., dz. cyt., s. 27.

10 Zob. М. Скабалланович, Толковый Типикон. Объяснительное изъяснение Типика с историческим введением, Издание Сретенского монастыря, Москва 2004, s. 438.

11 „I zaczynamy sześć psalmów, słuchając ich w milczeniu i rozrzewnieniu”. Porzadek jutrzni, tłum. ks. H. Paprocki, online: liturgia. cerkiew.pl /pages/File/docs/hora-03-jutrznia.pdf, dostęp: 03.10.2014, s. 2.
}

\section{Nabożeństwo eucharystyczne na podstawie VIII księgi „Konstytucji Apostolskich”}

„Konstytucje Apostolskie” stanowią ważny wczesnochrześcijański zabytek liturgiczny, w którym zachowały się dwa opisy Liturgii eucharystycznej. W schemacie zapisanym w VIII księdze „Konstytucji...”, który jest określany jako starsza wersja, przepisana $\mathrm{z}$ istniejącego, lecz współcześnie nieznanego rękopisu i datowana na około III wiek, również występuje modlitewna cisza ${ }^{12}$.

Liturgia VIII księgi rozpoczynała się od 5 czytań i homilii, po której następowała modlitwa za katechumenów. Nie była to jedna modlitwa, lecz należy mówić o grupie modlitw, które przebiegały następująco.

Katechumeni stawali na kolana. Pierwsza modlitwa odbywała się w milczeniu i na kolanach. Następnie diakon wygłaszał wezwanie ektenii katechumenów, na które jedynie wierni odpowiadali słowami: „Panie, zmiłuj się”. Katechumeni wstawali z kolan, zaś kapłan odczytywał drugą modlitwę. Katechumeni skłaniali swoje głowy, zaś kapłan odczytywał modlitwę skłonienia głów oraz błogosławił katechumenów (nakładał im dłonie na głowy), po czym wychodzili oni ze świątyni ${ }^{13}$.

Po wyjściu katechumenów wygłaszane były podobne modlitwy (tj. ektenia i modlitwa na skłonienie głów) nad opętanymi (ektenia, modlitwa, modlitwa egzorcyzmu), nad przygotowującymi się do sakramentu Chrztu, długa ektenia i modlitwa o pokutujących. Grupę modlitw kończyło wezwanie diakona: „Niech nikt z tych, którzy nie mogą, nie przybliża się. Jedynie wierni, skłońmy kolana. Pomódlmy się do Boga przez Chrystusa Jego..." W tym momencie następowała modlitwa w pełnym milczeniu ${ }^{14}$.

Schemat ten wskazuje na pierwszą modlitwę katechumenów, dokonywaną $\mathrm{w}$ milczeniu, w czasie kiedy nieochrzczeni stawali na kolana. Zarówno ich postawa, jak i forma modlitwy (w milczeniu), wskazuje na żarliwą indywidualną prośbę. Schemat $\mathrm{w}$ obrazowy sposób przedstawia również drogę do chrześcijaństwa, od pokory i zrozumienia własnej grzeszności, poprzez poszukiwanie zbawienia w Chrystusie, po wstawiennictwo wiernych, błogosławieństwo prezbitera bądź biskupa i ostateczne zjednoczenie z Chrystusem, które dokonuje się w trakcie sakramentu Chrztu.

Milczenie katechumenów wyraża również logiczny podział na tych, którzy poprzez sakrament Chrztu przynależą już do wspólnoty i jako wspólnota wiernych wznoszą swoje modlitwy i na tych, którzy jeszcze do tej wspólnoty

\footnotetext{
12 Porównanie dwóch schematów Liturgii „Konstytucji Apostolskich” oraz ich datacja zob. И. А. Карабинов, Лекции по литургике. Читанныля студентам (XIX) и (XX) курсов С. Петербургской Духовной Академии в 1911-1912 уч. году, Литография Богданова, Санкт-Петербург 1912, s. 55-58. Zob. również M. Ławreszuk, Nabożeństwo chrześcijańskie w IV wieku na podstawie „Konstytucji Apostolskich”, [w:] Elpis, 14 2012, s. $139-145$.

13 M. Ławreszuk, Modlitwa wspólnoty..., dz. cyt., s. 131.

14 М. Арранц, Евхаристия Востока и Запада, Москва 1999, s. 32.
} 
nie przynależą, i chociaż wypowiadają słowa próśb skierowanych do Boga, to nie mają jeszcze prawa na to, aby ich modlitwa była wspólnotowa. „Panie zmiłuj się” pada $\mathrm{z}$ ust wiernych dopiero po drugim diakońskim wezwaniu, w którym zwraca się on bezpośrednio do nich: „wierni, pomódlmy się za katechumenów".

\section{Modlitwa za wiernych w trakcie Liturgii}

Rozwinięcie schematu VIII księgi „Konstytucji Apostolskich" pojawia się w wielu późniejszych rękopisach i generuje podobną praktykę w odniesieniu do ektenii i modlitwy wiernych.

Nieżyjący już hiszpański liturgista, o. Miguel Arranz w swoich pracach przedstawił teorię rozwoju modlitw wiernych na Liturgii, opisując zmiany od postanowień Soboru w Laodycei, który w 19. kanonie wskazuje na konieczność 2 modlitw wiernych po modlitwie katechumenów. Na podstawie zachowanych rękopisów, Arranz rozdzielił modlitwę wiernych, po odejściu katechumenów na trzy części. Jego zdaniem tak sprawowana Liturgia była charakterystyczna dla przełomu VI i V wieków ${ }^{15}$.

Pierwsza część, podobnie jak w przypadku modlitwy katechumenów Liturgii VIII księgi „Konstytucji Apostolskich" odbywała się w milczeniu na kolanach. Drugą część rozpoczynało wezwanie diakona „Do Pana módlmy się”, po którym czytana była druga modlitwa, w czasie której wierni wciąż stali na kolanach. W treści tej modlitwy zawierały się prośby o pokój, o Kościół, o hierarchię, o narodzie Bożym. Trzecią część wyznaczała zmiana postawy wiernych, którzy wstawali z kolan, zaś diakon wskazywał na kolejne intencje, za które winna być wznoszona modlitwa: o anioła pokoju, o odpuszczenie grzechów. Końcem modlitwy wiernych była kapłańska modlitwa, po której następował „pokój”. Określenie „,pokój” można rozumieć trojako: jako błogosławieństwo „pokój wszystkim”, jako modlitwę na skłonienie głów, w której zawsze występuje pokój i światłość Oblicza Boga oraz jako braterski pocałunek pokoju ${ }^{16}$.

Schematyzacja modlitwy wiernych przedstawiona przez M. Arranza, zachowała się jeszcze w rękopisach Liturgii św. Bazylego Wielkiego z VIII-XI wieku ${ }^{17}$, która w tym okresie była częściej sprawowana aniżeli Liturgia św. Jana Chryzostoma.

\section{Ektenia w katedralnej tradycji konstantynopolitańskiej}

Powyższe wskazania na ciszę obecną w modlitwie za katechumenów i wiernych, zauważalne są również w kon-

\footnotetext{
5 Zob. tamże, s. 34.

16 Zob. tamże, s. 46-47.

17 Źródła liturgiczne: Barberini 336 (VIII w.), Peterburg 226 (ze zbiorów biskupa Porfiriusza X w.), Sevastjano 474, Sinai 959, zwoju Topkapi (Istanbul Topkapi Sarai G.i.51), Ateny 662. Zob. M. Арранц, Eвхаристия Востока и Запада, dz. cyt., s. 37.
}

stantynopolitańskiej praktyce katedralnej. Ektenia tradycji katedralnej składała się z sześciu części. Ektenię rozpoczynało wezwanie diakona do modlitwy. To, co współcześnie stanowi pierwsze wezwanie ektenii $\mathrm{w}$ tradycji katedralnej wyglądało następująco:

1. Diakon: ,Jeszcze i jeszcze, skłoniwszy kolana, do Pana módlmy się". Wierni stawali na kolana. Odpowiedzią na to pierwsze wezwanie nie były słowa „Panie, zmiłuj się”. Faktyczną odpowiedzią był gest - skłonienie kolan dokonywane w ciszy.

2. Kolejne wezwania diakona dotyczyły próśb uniwersalnych, troski o cały świat, o Kościół powszechny itd. Wierni stojąc na kolanach odpowiadali słowami „Panie, zmiłuj się".

3. Przejście z kolan do pozycji wyprostowanej dokonywało się $\mathrm{w}$ trakcie zmiany wezwań od próśb uniwersalnych do indywidualnych, bądź po wezwaniu diakona: „Wspomóż, zbaw, zmiłuj się, podnieś i ochroń nas, Boże, łaską Twoją"18. To wezwanie zachowało się we współczesnych tekstach liturgicznych „Triodionu Paschalnego" na wieczerni niedzieli Pięćdziesiątnicy.

Powyższe świadectwa jednoznacznie wskazują na początek ektenii dokonywany w milczeniu. Stąd zresztą może pochodzić nazwa pierwszej i najdłuższej ektenii, tzw. ektenii pokoju (cs. мирная ектения). Cisza nie jest przy tym pasywna, lecz stanowi indywidualną modlitwę wiernego. Podobny charakter ciszy w nabożeństwie odnaleźć możemy jeszcze w nabożeństwach okresu Wielkiego Postu.

\section{Cisza w nabożeństwach Wielkiego Postu tradycji jerozolimskiej}

W XII-XIII wieku, w wyniku syntezy studyjskiej i jerozolimskiej tradycji liturgicznej, pojawiają się „Typikony" tzw. neopalestyńskiej redakcji. W rękopisach tychże typikonów możemy odnaleźć następującą informację o czytaniu modlitwy św. Efrema Syryjczyka: ,stajemy na krótki czas, modląc się w sobie, w myślach [tj. w milczeniu], [słowami] modlitwy św. Efrema «Panie i Władco», następnie wszyscy, skłoniwszy kolana na ziemię, wygłaszamy tą modlitwę z trzema pokłonami, poprzedzani igumenem bądź eklezjarchą. Następnie czynimy kolejne 11 pokłonów [w innej redakcji 12 pokłonów] powoli, ażeby dorównać wszystkim, w czasie 12 pokłonu wygłaszamy wskazaną modlitwę kolejny raz, a następnie wstajemy"19.

\section{Cisza i śpiew w synajskiej praktyce monastycznej}

O tym, że śpiew i cisza obecne były w nabożeństwie tradycji monasterskiej świadczy także „Pandektion” igumena Nikona z Czarnej Góry. W księdze tej zapisana

\footnotetext{
18 М. Арранц, Евхаристия Востока и Запада, dz. суt., s. 47-49. M. Ławreszuk, Modlitwa wspólnoty..., dz. cyt., s. 296.

19 И. Д. Мансветов, Церковный устав..., dz. суt., s. 213-214.
} 
jest historia wizyty dwóch palestyńskich mnichów, Jana Moschosa (+619) i św. Sofroniusza (+638, późniejszego patriarchy jerozolimskiego) u abby Nila na Górze Synaj około $606 \mathrm{roku}^{20}$. Relacja z wizyty mnichów zawierała opis nabożeństwa nocnego czuwania, które rozpoczynało się wieczorem i trwało przez całą noc ${ }^{21}$. W porównaniu z praktyką palestyńską przełomu VI i VII wieku, w pustelni synajskiej śpiew ustępował czytaniu modlitw i psalmów, a znana już w Palestynie hymnografia ustępowała na rzecz czytań i ciszy. $\mathrm{W}$ rozmowie z palestyńskimi mnichami Abba Nil określa siebie jako osobę „milczącą”, co winno charakteryzować mnichów. „Milczącym i tym którzy płaczą o swoich grzechach, nie wypada śpiewać troparionów". ${ }^{22}$ Ta epizodyczna historia, rozpowszechniona w „Pandektionie”, przywoływana była w chrześcijaństwie niejednokrotnie, przez co inspirowała usprawiedliwienie ciszy, pokajaniem i poczuciem grzeszności. Jak wkrótce zauważymy, odcisnęło to swoje piętno na nabożeństwach prawosławnych, szczególnie w okresie Wielkiego Postu.

\section{Początek całonocnego czuwania}

Wśród wspomnianych historycznych wskazań dotyczących ciszy w nabożeństwie, nie mówiliśmy o przykładach, które możemy zaobserwować współcześnie. Jednym z nich, jest początek nabożeństwa całonocnego czuwania. We współczesnej słowiańskiej praktyce, całonocne czuwanie rozpoczyna się od okadzenia świątyni, przy czym duchowny okadza prezbiterium w ciszy, a dopiero później wygłasza początkowe wezwanie: „Chwała Świętej, i jednoistotnej, i życiodajnej, i niepodzielnej Trójcy, w każdym czasie, teraz i zawsze, i na wieki wieków" (cs. Слава Святей...). Najważniejsze miejsce, w którym rozpoczyna się nabożeństwo jest okadzane w ciszy. Zgodnie z regułą „Typikonu” cisza ta nie ogranicza się jednak tylko do prezbiterium. Skabałanowicz zauważa, że całe okadzenie świątyni powinno odbywać się w ciszy, albowiem reguły mówią, iż dopiero zakończywszy okadzanie, prezbiter powraca przed św. ołtarz i wygłasza początkowe wezwanie ${ }^{23}$. Milczenie w tym momencie wskazuje na okadzenie jako na ważny i samodzielny element nabożeństwa.

\section{Co oznacza cisza w nabożeństwie}

Prawosławna tradycja liturgiczna to harmonia werbalnych i niewerbalnych elementów. Słyszalne modlitwy, wezwania diakona, dziękczynienia, prośby, hymny oraz wersety Pisma Świętego splatają się z elementami, które nie wydają dźwięku, a jednocześnie stanowią nośnik treści. Ikona, gesty, ruch kapłana w trakcie nabożeństwa, za-

\footnotetext{
20 М. Скабалланович, Толковый Типикон..., dz. cyt., s. 294.

21 Opis nabożeństwa, patrz: M. Ławreszuk, Modlitwa wspólnoty..., dz. cyt., s. 229-231.

22 М. Скабалланович, Толковый Типикон..., dz. суt., s. 296.

23 Tamże, s. 413.
}

pach kadzidła - to wszystko oddziałuje na inne niż słuch zmysły. Lecz wszystko razem i dźwięk i obraz i zapach, harmonijnie splatają się ze sobą oddziałując na serce, które, jak stwierdził o. Alciviadis C. Calivas jest „dotknięte przez głęboką ciszę Boskiej obecności”24.

Opierając się na Biblii musimy stwierdzić, iż cisza staje się odzwierciedleniem Boskiej wszechmocy i obecności. Przed Jego obliczem człowiek może stać z modlitwą dziękczynną bądź bładalną, może adorować Jego wielkość, lecz może też stać się uczestnikiem Bożej obecności.

Prorok Habakuk wzywał: „Pan mieszka w świętym domu swoim, niechaj zamilknie przed Nim cała ziemia" (Ha 2,20). Dziedzictwo biblijne wskazuje, że milczenie i cisza nie są jedynie oznaką czci i pokory, lecz stanowią również możliwość odbioru. Jedynie w ciszy człowiek może usłyszeć głos Boży, który pozwoli mu odnaleźć prawidłową ścieżkę. Tak postąpił sługa posłany przez Abrahama w celu odnalezienia żony dla Izaaka: „On zaś zdziwiony czekał w milczeniu, aby się przekonać, czy Pan pozwoli mu dopiąć celu podróży czy nie" (Rdz 24,21). Ten element jest szczególnie aktualny w prawosławnej tradycji liturgicznej, w której, jak mówił św. Jan Chryzostom, zanim wzniesione zostaną wszelkie modlitwy i dziękczynienia, należy najpierw wysłuchać tego, co Bóg pragnie przekazać człowiekowi. Dlatego też, w prawosławnej Liturgii jej historyczne początkowe elementy, tj. czytanie Pisma Świętego oraz homilia, stanowią przede wszystkim lekcję i pouczenie. Człowiek, który uczestniczy w Boskiej Liturgii, najpierw wysłuchuje słów Boga i Jego uczniów, by dopiero później wznieść dziękczynną ofiarę i żarliwe modlitwy. W prawosławnym modlitewniku często znajduje się wstępna instrukcja, która głosi: „Postój w milczeniu, aż do chwili kiedy wszystkie zmysły się wyciszą, w swojej świadomości przyjmij Boską obecność, odczucie bliskości przyjmij z pokornym strachem i napełnij swoje serce żywą wiarą w to, że Bóg słyszy i widzi ciebie"25.

Odpowiednikiem tej gotowości, którą człowiek osiąga przez skupienie i zwrócenie się w stronę Boga, mogą być słowa zachęty wygłaszane przez diakona w trakcie nabożeństwa. „Bądźmy uważni” (cs. вонмем). Skabałanowicz słowa diakona komentuje następująco: „diakon zamyka usta wszystkim przykazaniem milczenia, okazując tym samym szacunek nie dla lektora, lecz dla Tego, który mówi poprzez niego"26. Odpowiednikiem tych słów w tradycji mozarabskiej były słowa: „Zachowajcie milczenie” (łac. silentium facite ${ }^{27}$.

Cisza, stanowiąca ważny filar prawosławnej ascezy i duchowości monastycznej, również w nabożeństwie, wskazywała na niezbędne w modlitwie otwarcie się na Boga. Nabożeństwo nie jest jednokierunkowe, nie stanowi monologu, lecz tworzy mistyczny dialog Cerkwi ze Stwórcą.

\footnotetext{
24 Alciviadis C. Calivas, The Sacramental Life of the Orthodox Church, online: http://www.goarch.org/ourfaith/ourfaith7106, dostęp: 3.10.2014.

25 Za: A. Mień, Sakrament Stowo Obrzęd. Prawostawna Stużba Boża, Łuków 1992.

26 М. Скабалланович, Толковый Типикон..., dz. суt., s. 138.

27 Tamże, s. 471.
} 
Momenty milczenia, stanowią duchowy impuls do dalszej modlitwy, lecz również niezbędny czas do tego, aby usłyszeć głos Boga. Dlatego mnisi egipscy oraz ich spadkobiercy po każdym psalmie stali w milczeniu.

„Cały organizm kościelny potrzebuje teraz ciszy, i wszyscy postanawiają w szczerze modlić się w swoich sercach. Prezbiterzy przebywają w ciszy, diakoni stoją w milczeniu, wszyscy zaś ludzie spokojni, i cisi, pokorni i wstrzemięźliwi. Głęboka cisza i pełen miłości spokój spoczywa w tym miejscu"28. We współczesnej praktyce liturgicznej niezwykle wartościowe może stać się ponowne odkrycie tej starej chrześcijańskiej myśli i przywrócenie ciszy miejsca w nabożeństwie. Kapłańskie modlitwy, które przez swoją głębię mają za zadanie prowadzić człowieka przed Boże oblicze, a które na nieszczęście są czytane w ciszy, nie zastąpią starej praktyki chwil ciszy w nabożeństwie. Nawet same modlitwy, chociaż ciche, nie są odczytywane w ciszy świątyni. Na to miejsce wkroczył śpiew, który jakby w obawie przed milczeniem objął chwilę najważniejszych modlitw wieczerni, jutrzni czy Liturgii, swoją rozwiniętą treścią i formą. Cisza została zapełniona śpiewem, lecz przy tym, jak wskazuje Nikołaj Afanasjew, w momencie sprawowania ofiary eucharystycznej ,wierni mało uczestniczą w jej dokonaniu"29.

Cisza w nabożeństwie wskazuje również na tajemnicę. Najstarsze kodeksy liturgiczne wskazują, iż sama proskomidia była pierwotnie sprawowana w ciszy. Dopiero VIII w. po raz pierwszy wskazuje na modlitwę proskomidii, i co należy podkreślić, była to pierwsza, i przez długi czas jedyna modlitwa. Podobnie, jak w momencie wniesienia Św. Darów w trakcie Liturgii uprzednio poświęconych Darów, cisza $\mathrm{w}$ trakcie proskomidii akcentowała tajemnicę i niepoznawalność Bożą, a jednocześnie Jego wielką kenozę, wobec której milknie wszelkie słowo i wszelka prośba.

Kolejny impuls do ciszy w nabożeństwie objawiają nam nabożeństwa wielkopostne, szczególnie Liturgia uprzednio poświęconych Darów oraz Liturgia Wielkiej Soboty.

W trakcie przeniesienia Świętych Darów na Liturgii uprzednio poświęconych Darów, duchowieństwo, chór

28 Р. Ф. Тафт, Статьи. II..., dz. суt., s. 287.
Н. Н. Афанасьев, Трапеза Господня, Париж 1952, s. 84. i wierni milczą. Oto niesiony jest sam Chrystus, Zbawiciel, który ofiarował siebie w ofierze za człowieka. W tym momencie wierni stają na kolanach i skłaniają swoje głowy do ziemi. Cisza staje się modlitwą pokory i dziękczynienia. Pokajanie, które charakteryzuje okres Wielkiego Postu, objawiając ludzką grzeszność i słabość w jeszcze większy sposób objawia bezmierną przepaść pomiędzy upadłą ludzkością a świętością do której Bóg ludzi powołał. W tym zestawieniu kenoza Syna Bożego staje się niezmierzalna i bezgraniczna. Spotkanie z Bożą kenozą w naturalny sposób prowadzi ludzi do pokornego milczenia i pełnego skruchy pokłonu. Cisza staje się naturalną odpowiedzią na paradoks Bożego uniżenia i Bożej ofiary.

Milczenie Wielkiej Soboty wyraża się w troparionie tonu 8 , który jest śpiewany zamiast Hymnu Cherubinów. „Niechaj milczy wszelkie ciało, niech stoi z bojaźnią i drżeniem, i nie myśli o niczym, co ziemskie. Oto Król królów i Pan panujących przychodzi, złożyć Siebie w ofierze i dać na pokarm wiernym. Poprzedzają zaś Go chóry aniołów, ze wszelką władzą i potęgą, wielooczni cherubini i sześcioskrzydli serafini, zakrywający oblicza i śpiewający pieśn: Alleluja”. Cisza tego dnia jest wskazana przez cerkiewną hymnografię. O jej charakterze wyraźnie pisze o. Aleksander Mień: „Ewangeliści milczą o tym, co przeżyli i o czym myśleli w tę paschalną sobotę. Ich milczenie niesie jednak treść ważniejszą od wszelkich słów. Apostołowie przebywali w ciszy. Straszna była to cisza, cisza rozpaczy. A niewiasty? One zaś czekały, kiedy skończy się sobota i będzie można wypełnić ostatni obowiązek miłości:

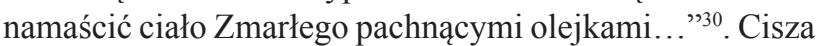
Wielkiej Soboty to cisza oczekiwania, zadumy i żalu, lecz jednocześnie płomiennej nadziei. W chwili kiedy Zbawiciel „leży ciałem w grobie”, człowiek powinien odrzucić wszelkie impulsy swojej woli, a nawet przesunąć na dalszy plan zbędne w tym momencie prośby i dziękczynienia. W tym przypadku, przyczyna ciszy kryje się w tajemnicy Bożej ofiary, która w nabożeństwie staje się „niewypowiedziana". Nawet najpiękniejsze i najbardziej głębokie w swej treści hymny i modlitwy ustępują przed tajemnicą Bożej miłości.

30 A. Mień, Sakrament Stowo Obrzęd. Prawosławna Stużba Boża, Łuków 1992.

\section{Bibliografia}

Афанасьев Н. Н., Трапеза Господня, Париж 1952.

Алымов В., Лекиии по Исторической Литургике, Holy Trinity Orthodox School, maszynopis, http://www.holytrinitymission.org/books/russian/historical_liturgics_v_ alimov.zip, 16.06.2012.

Арранц М., Евхаристия Востока и Запада, Москва 1999.

Calivas Alciviadis C., The Sacramental Life of the Orthodox Church, online: http://www.goarch.org/ourfaith/ourfaith7106, dostęp: 3.10.2014.

Голубцов А. П., О причинах и времени замены гласного чте- ния литургийных молитв тайными, [w:] Богословский вестник, 1905, nr 9, s. 69-70.

Карабинов И. А., Лекции по литургике. Читанныя студентам $(X I X)$ и $(X X)$ курсов С. Петербургской Духовной Академии в 1911-1912 уч. году, Литография Богданова, Санкт-Петербург 1912.

Ławreszuk M., Modlitwa wspólnoty: historyczny rozwój prawostawnej tradycji liturgicznej, Wydawnictwo Uniwersytetu w Białymstoku, Białystok 2014.

Ławreszuk M., Nabożeństwo chrześcijańskie w IV wieku na 
podstawie „Konstytucji Apostolskich”, [w:] Elpis, 14 2012, s. $139-145$.

Мансветов И. Д., Церковный устав (Типик), его образование и судьба в греческой и русской иеркви, Москва 1885.

Mień A., Sakrament Stowo Obrzęd. Prawosławna Stużba Boża, Łuków 1992.

Paprocki H., Misterium Eucharystii. Interpretacja genetyczna Liturgii bizantyjskiej, Wydawnictwo WAM, Kraków 2010.

Porzadek jutrzni, thum. ks. H. Paprocki, online: liturgia.cerkiew. $\mathrm{pl} /$ pages/File/docs/hora-03-jutrznia.pdf, dostęp: 03.10.2014.
Скабалланович М., Толковый Типикон. Объяснительное изъяснение Типика с историческим введением, Издание Сретенского монастыря, Москва 2004.

Тафт Р. Ф., Евхаристическая Анафора возносилась тайно или гласно? [w:] Статьи. II. Литургика, Р. Ф. Тафт, Голованов, Омск 2011, s. 253-302.

Тафт Р. Ф., Было ли традиционно для ранней Церкви чтение вслух литургических молитв? [w:] Статьи. ІІ. Литургика, Р. Ф. Тафт, Голованов, Омск 2011, s. 303-310.

Rozmiar artykułu: 0,7 arkusza wydawniczego 
ISSN 1508-7719

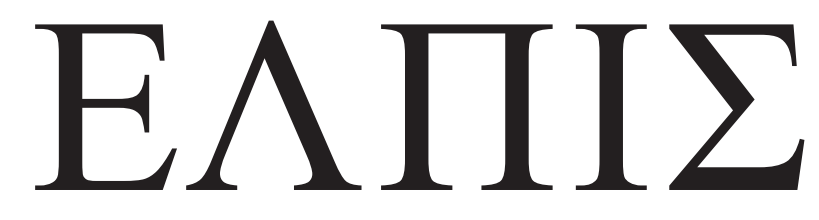

CZASOPISMO TEOLOGICZNE KATEDRY TEOLOGII PRAWOSŁAWNEJ UNIWERSYTETU W BIAŁYMSTOKU

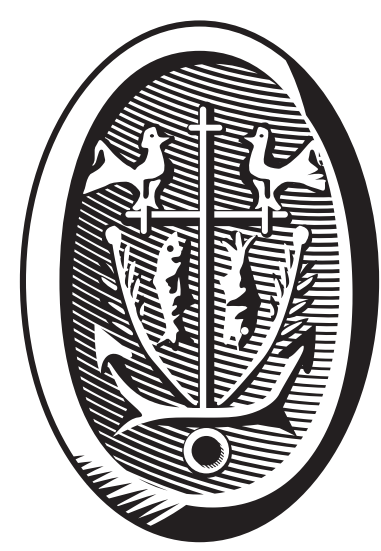

ADRES REDAKCJI

15-097 Białystok, ul. M. Skłodowskiej-Curie 14 tel. 85 745-77-80, e-mail: redakcja@elpis.edu.pl www.elpis.uwb.edu.pl 